\title{
Have The Lessons Learned from The Asian Financial Crisis Been Applied Effectively in Asian Economies?
}

\author{
Masaharu Kanaoka \\ Macroeconomic Quality Research Center \\ 2-9-7 Miyano-machi Fuchu-cho, Akigunn, Hiroshima, Japan \\ Tel: 81-082-283-9683Ｅ-mail: masaharu661250@ybb.ne.jp
}

Received: August 14, 2011

Accepted: November 4, $2011 \quad$ Published: February 1, 2012

doi:10.5539/ijef.v4n2p103

URL: http://dx.doi.org/10.5539/ijef.v4n2p103

\begin{abstract}
To improve the quality of economic managements, this paper attempts to determine whether the lessons of the 1997 Asian financial crisis were effectively applied in Asian economies in the mid-2000s and whether the application mitigated the shocks of the global financial crisis in 2008. We find that many Asian economies applied the lessons effectively but with some exceptions. Compared to mid-1990s, the ratio of the external short-term debt by private creditors to the foreign reserves and the current account deficits improved in almost all the Asian economies in mid-2000s. The total external debts decreased in most economies, specifically in those heavily damaged during the Asian financial crisis. However, some economies seemed to pay little attention to the lessons, as evidenced by the exceptions in the total external debts (the Philippines etc) and in the growth of claims on the private sector (Vietnam etc). Various phenomena during crises also improved, which included the reversal of capital inflow through external bank loans, currency depreciations, changes in the growths of credits to the private sector, and increases in the real external debt burden in domestic currency. However, two areas declined: portfolio investment inflows reversed and export growth decreased. Every economy is advised to apply the lessons learned by the other economies and to prepare for crises in the future.
\end{abstract}

Keywords: The Asian financial crisis, The global financial crisis, Lessons learned, External debt, Foreign reserves, Claims on private sectors, Portfolio liabilities, Export growth

Classification codes: G01 - Financial Crises, G15 - International Financial Markets

\section{Introduction}

Plan-Do-Check-Act (PDCA) is the most important process of quality control in the manufacturing industry. Through this process, product and system qualities are improved by incorporating the lessons learned from past experiences. The same process is required to improve the management of an economy. The most important step for the improvement of quality is to recognize the related facts correctly to check whether the lessons learned in the past are effectively applied to the economic system operation and their outputs. Unfortunately there are few researches on this purpose for the Asian economies. This paper examines whether the lessons from the 1997 Asian financial crisis were applied to the macroeconomic operations of 18 Asian economies (Note 1) in the 2000s, and whether the resulting improvements to these economies helped to mitigate the shocks caused by the global financial crisis in 2008. We first review in section 2 the research on the last two major crises for the Asian economies, the Asian financial crisis in 1997 and the global financial crisis in 2008. Next, in section 3 we develop a theoretical model as the basis of the empirical analysis, and in section 4 the data sources are elaborated. In section 5 we compare macroeconomic factors in advanced five economies between the two crises. Then in section 6 we compare macroeconomic factors between the two pre-crisis periods in the Asian economies, and in section 7 further analyze various phenomena during the crisis periods. Based on this analysis, we identify the macroeconomic factors to which these lessons were applied and to which not applied in individual economies.

\section{Literature Review}

In this section we will review the research on the last two major crises for the Asian economies, the Asian financial crisis in 1997 and the global financial crisis in 2008.

\subsection{Literature Review on the Asian Financial Crisis in 1997}

The causes of the Asian financial crisis have been discussed from two kinds of aspect, financial and trade. First from 
the financial aspect, it is one of a consensus that the Asian financial crisis was triggered by the illiquidity in Thailand, indicated by the ratio of short-term debt to reserves. Radelet, Sachs, Cooper, and Bosworth (1998), Bussière and Mulder (1999) and Caramazza, Ricci and Salgado (2000) found in their regression analyses that the ratio of short-term debt to reserves was strongly associated with the crisis. The reason for the increased short-term debt was large capital inflows from abroad starting from the liberalization of capital flows between domestic and foreign markets in the beginning of 1990s. Radelet et al. (1998) indicated that the ratio of the capital account to GDP was strongly associated with the crisis. The increasing current account deficits existed in the background of the large capital inflows from abroad, and the fact that the ratio to current account deficits to GDP are significantly correlated with the crisis was proved through the regression analyses by Glick and Rose (1999), Bussière et al. (1999), Gregorio and Valdès (2001), Caramazza et al. (2000) and Corsetti, Pesenti, and Roubini (2001).

In the domestic economies, the capital inflows, attracted by high interest rates in Asian economies, were more than compensating their current account deficits, and the excess capital inflow caused lending booms, which means rapid increases in the claims of the financial sector on the private sector, and caused large percentage of nonperforming loans. Radelet et al. (1998), Glick et al. (1999), Gregorio et al. (2001) and Corsetti et al. (2001) found the fact that a rapid increase in the ratio of the claims on the private sector relative to GDP was significantly correlated with the crisis.

Secondly from the trade aspect, Glick et al. (1999) found that the trade channel for contagion is consistently important. Gregorio et al. (2001) found that the trade links are a relevant propagation mechanism for contagion, however, they are no longer important when they control for the neighborhood effect. Forbes (2002) observed on the trade effect that "the competitiveness effect and income effects are both negative, significant and economically important. There is also weak evidence of a positive cheap-import effect". He analyzed countries in two groups and found that "the competitive effect is only large and significant when a crisis country allows its currency to be devalued (or depreciate) substantially." His results also suggest that "the income effect is only large and significant when a crisis country raises interest rates substantially".

\subsection{Literature Review on the Global Financial Crisis in 2008}

The causes of the global financial crisis in 2008 have been discussed similarly from two kinds of aspect, financial and trade. First from the financial aspect, illiquidity is one of causes as in the Asian financial crisis in 1997. Lane and Milesi-Ferretti (2010) and Blanchard, Faruqee, and Das (2010) found that the "ratio of reserves to short-term external debt" is significant in explaining the severity of the crisis. However, Blanchard et al. (2010) added that the effect comes mostly from short-term debt rather than from reserves. On the other hand, Llaudes, Salman, and Chivakul (2010) and Lane et al. (2010) found that reserves helped dampen the impact of the crisis on emerging market economies. Other than short-term debt, Berkmen, Gelos, Rennhack and Walsh (2009) showed that "a larger stock of lending from advanced countries contributed to a more severe downward revision of the growth forecast". The similar results were indicated by Lane et al. (2010) and Llaudes et al. (2010). As was in the Asian financial crisis, the fact that the ratio to current account deficits to GDP are significantly correlated with the crisis was proved through the regression analyses by Lane et al. (2010) and Blanchard et al. (2010).

In the domestic economies, similar to the Asian financial crisis, Berkmen et al. (2009), Lane et al. (2010) and Llaudes et al. (2010) found that a higher ratio of private credit to GDP and a larger increase in that ratio affected the severity of a crisis. Berkmen et al. (2009) and Llaudes et al. (2010) found in addition that the severity was more pronounced for countries with fixed exchange rate regimes.

Second, from the trade aspect, Blanchard et al. (2010) determined from their regression analyses for 29 countries that the variables of "unexpected trading-partner growth" were significant in explaining "unexpected GDP growth" in emerging economies. Llaudes et al. (2010) found that "emerging market economies with higher dependence on demand from the advanced economies experienced sharper falls in output during the crisis." Berkmen et al. (2009) and Lane et al. (2010) further found that the share of manufacturing products in total exports (or in GDP) is correlated with worse growth performance.

These studies indicate that both financial and trade effects are important factors in explaining an economy's involvement in a financial crisis.

\section{A Model}

This paper develops a model based on the model by Blanchard et al. (2010), who assumed "a standard short-run, open economy model, modified, however, in two important ways. First, to capture the effects of shifts in capital flows, we allow for imperfect capital mobility. Second, we allow for potentially contractionary effects of a depreciation stemming from exposure to foreign currency debt." This paper is based on these assumptions except the 
assumption of short-run because we handle rather long periods and can not neglect price level changes which differ according to the economies. We also follow Blanchard et al.'s (2010) explanation that "The model is shamelessly ad hoc, static, and with little role for expectations." except the assumption of "with little role for expectations." for we are not sure "the direct effect of lower exports and lower capital flows probably dominated expectational effects". The model by Blanchard et al. is composed of two relationships, the first one representing the balance of payments equilibrium and the second one representing the goods market equilibrium. In this paper, we add a relationship representing the money market equilibrium to consider the effect of money supply and price level changes during crises.

\subsection{Balance of Payments Equilibrium}

Following Blanchard et al. (2010), we consider two different interest rates:

“- the interest rate at which domestic borrowers (firms, people, and the government; we make no distinction among them in the model) can borrow, denoted by $r^{\wedge \prime}$;

"- the U.S. dollar interest rate, that is, the rate at which foreign investors can lend to foreign borrowers abroad, denoted $r^{* \prime}$.

If perfect capital mobility and interest rate equilibrium are realized, then the domestic interest rate equals the sum of the interest rate abroad " $r$ ", risk premium " $x$ " and expected depreciation rate of the domestic currency " $(\Delta e / e)_{\text {exp }}$ ". However, because we allow for imperfect capital mobility, the equilibrium does not hold, and the difference between the domestic interest rate and the sum of the interest rate abroad, risk premium and expected depreciation rate, " $r$ ^ $r^{*}-x-(\Delta e / e)_{e x p}$, , induces a capital flow in or out.

As Blanchard et al. (2010) assumed, equilibrium in the balance of payments requires that "the trade deficit be financed either by net capital flows or by a change in reserves". We also follow their assumption that "all foreign borrowing is in dollars, so that foreign investors can choose between foreign and domestic dollar-denominated assets. Let " $D$ " be debt vis-à-vis the rest of the world, expressed in dollars". We assume then that net capital inflows " $F$ " (capital inflows minus capital outflows and interest payments on the debt, denominated in US dollars) depend on the interest-rate spread, adjusted for a risk premium and expected depreciation rate, and negatively on foreign debts.

$\left.\mathrm{F}\left(\mathrm{r}^{\wedge}-\mathrm{r}^{*}-\mathrm{x}-(\Delta \mathrm{e} / \mathrm{e})\right)_{\text {exp }}, \mathrm{D}\right)$.

Assume that the balance of payments equilibrium condition is represented by (Note 2)

$$
\mathrm{F}\left(\mathrm{r}^{\wedge}-\mathrm{r}^{*}-\mathrm{x}-(\Delta \mathrm{e} / \mathrm{e})_{\exp }, \mathrm{D}\right)+\mathrm{e}\left[\mathrm{EX}\left(\mathrm{eP} / \mathrm{P}, \mathrm{Y}^{*}\right)-\mathrm{IM}(\mathrm{eP} / \mathrm{P}, \mathrm{Y})\right]=\Delta \mathrm{R},
$$

where " $\mathrm{e}$ " is the nominal exchange rate defined as US dollars per domestic currency, " $\mathrm{P}$ " and " $\mathrm{P}$ " are the foreign and domestic price level respectively, " $Y *$ " and " $Y$ " are the foreign and domestic economic output respectively. " $\Delta R$ " is the change in foreign reserves in dollars. (Here, " $F$ ", " $D$ ", " $Y^{*}$ ”, " $R$ ", and " $\Delta R$ " are denominated in US dollars.) As Blanchard et al. (2010) assumed, "a decrease in domestic economic activity " $Y$ " leads to a decrease in imports "IM" and an improvement in net exports, and a decrease in foreign activity " $Y$ " leads to a decrease in exports " $E X$ " and thus a decrease in net exports". Because the Marshall-Lerner (ML) condition may not hold during the crisis period, we do not know whether a positive or a negative sign to be assigned to the effect of the currency depreciation on net exports.

\subsection{Goods Market Equilibrium}

We assume that equilibrium in the goods market, denominated in domestic currency, is represented by

$$
\mathrm{Y}=\mathrm{A}\left(\mathrm{Y}, \mathrm{r}^{\wedge}, \mathrm{D} / \mathrm{e}\right)+\mathrm{G}+\mathrm{EX}\left(\mathrm{eP} * \mathrm{P}, \mathrm{Y}^{*}\right)-\mathrm{IM}(\mathrm{eP} / \mathrm{P}, \mathrm{Y}),
$$

where, similar to the model by Blanchard et al. (2010), “ " $A$ " is domestic private demand and " $G$ " is government spending denominated in the domestic currency. Domestic private demand, " $A$ ", depends positively on income $Y$, negatively on the domestic borrowing rate " $r$ ", and negatively on foreign debt " $D / e$ ", expressed in terms of domestic goods. This last term captures foreign currency exposure and balance sheet effects; the higher the foreign debt (which we have assumed to be dollar debt), the larger the increase in the real value of the debt from a depreciation and the stronger the adverse effect on output"

\subsection{Money Market Equilibrium}

Assume that equilibrium in the money market is given by

$$
\mathrm{M} / \mathrm{P}=\mathrm{L}_{1}\left(\mathrm{r}^{\wedge}, \mathrm{Y}\right),
$$

where " $M$ " is the money supply and " $P$ " denotes domestic price level as noted above. The lower the interest rate 
" $r$ " ' is and the higher the domestic economic activity " $Y$ ", the larger the demand of real money supply " $M / P$ ".

\subsection{Domestic Output and Related Factors}

Based on the theoretical model above, we select the factors that determine the domestic outputs for our empirical analysis. We focus on the output growth and the related factors. We organize these factors from two perspectives, trade and financial transactions. From the perspective of trade transactions, we begin with formula (2) of the goods market equilibrium. By inserting " $\mathrm{r} \wedge=\mathrm{L}_{2}(\mathrm{Y}, \mathrm{M} / \mathrm{P})$ ", rearranged from formula (3), into formula (2) and solving for output " $Y$ ", " $Y$ " is represented by the following function:

$$
\mathrm{Y}=\mathrm{Y}(\mathrm{M} / \mathrm{P}, \mathrm{D} / \mathrm{e}, \mathrm{G}, \mathrm{EX}, \mathrm{eP} * \mathrm{P}) \text {. }
$$

From the perspective of financial transactions, we start from formula (1) of the balance of payments equilibrium. By inserting " $[E X-I M]=\{\Delta R-F\} / e$ ", rearranged from formula $(1)$, and " $\mathrm{r} \wedge=\mathrm{L}_{2}(\mathrm{Y}, \mathrm{M} / \mathrm{P})$ ", rearranged from formula (3), into formula (2) and solving for output " $Y$ ", " $Y$ " is represented by a function as follows: (Note 3)

$$
\mathrm{Y}=\mathrm{f}\left(\mathrm{M} / \mathrm{P}, \mathrm{D} / \mathrm{e}, \mathrm{G}, \Delta \mathrm{R}, \mathrm{r}^{\wedge}-\mathrm{r}^{*}, \mathrm{x},(\Delta \mathrm{e} / \mathrm{e})_{\mathrm{exp}}, \mathrm{D}, \mathrm{e}\right) .
$$

When we take formulas (4), (5) and rearranged formula (1) " $[\mathrm{EX}-\mathrm{IM}]=\{\Delta \mathrm{R}-\mathrm{F}\} / \mathrm{e}$ " into consideration, output " $Y$ " is related to the following macroeconomic factors (Note 4):

1. Foreign debt denominated in dollars: $D$

2. Risk indicator: $x$

3. Net capital inflows: $F$

4. Money supply denominated in national currency: $M / P$

5. Exports: $E X$

6. Currency exchange rates: $e$

7. Interest rate spread between domestic lending rate and international lending rate: $r^{\wedge}-r^{*}$

8. Foreign debt denominated in domestic currency: D/e

9. Government consumption denominated in national currency: $G$

10. Domestic lending interest rate: $r^{\wedge}$

11. Effective exchange rate: $e P^{*} / P$

12. Expected depreciation rate of the domestic currency: $(\Delta e / e)_{\text {exp }}$

13. Change in foreign reserves expressed in dollars: $\Delta R$

The output growth " $\Delta Y$ " is related to these macroeconomic factors and their changes. In the following analyses we analyze the factors from No. 1 to 8. Other factors, related to policies, are left for future study.

\section{Data Sources}

The main sources of the data used in this paper are the International Financial Statistics (IFS) "eLibrary" by the International Monetary Fund (IMF) and Global Development Finance by the World Bank (WB). Some complementary data are obtained from the Asian Development Bank (ADB) database. Some of the data for the economy of Taiwan are obtained from the database of the Central Bank of the Republic of China (Taiwan). Annual data are used in this analysis because quarterly data are not always available for most of the economies analyzed in this paper. The data sources of the data for the five advanced economies are IFS "eLibrary".

\section{The Status of Advanced Economies}

The status of advanced economies affects the expansion of the crisis to the rest of the world because these economies are important partners in both trade and financial transactions. We review the status of the five advanced economies before and during two crises, the Asian financial crisis in 1997 and the global financial crisis in 2008. The five advanced economies are the United States, the United Kingdom, Japan, Germany and France, which comprise approximately half of the world's trade and financial transactions. Table 1 shows the related indicators for the three-year averages prior to each crisis, from 1994 to 1996 (mid-1990s) and from 2005 to 2007 (mid-2000s). This table also shows the change in the indicators from the three-year average before each crisis to the end of each crisis (assumed 1998 and 2009, respectively). During the Asian financial crisis, the average GDP volume change decreased slightly, whereas during the global financial crisis, it dropped from a positive to a significantly negative value. Similarly, the 1-Year LIBOR changed little during the Asian financial crisis, whereas during the global financial crisis, it dropped significantly. Regarding the financial investment in BOP, the annual flows of the other 
investment net assets from the 5 economies to the rest of the world kept an outflow decreasing by approximately 60 percent during the Asian financial crisis, whereas during the global financial crisis, the annual flow reversed, from an outflow before the crisis to an inflow in 2009. The annual outflows of the portfolio investment net assets from the 5 economies increased slightly from the mid-1990s to 1997, whereas, during the global financial crisis, the flow reversed from an outflow before the crisis to an inflow in 2008. Because portfolio investments respond more rapidly than other investments, the flow reversed to an inflow in 2008 and returned to an outflow again in 2009. The goods imports total in BOP for the five advanced economies increased slightly during the Asian financial crisis, whereas it decreased dramatically during the global financial crisis. As Table 1 indicates, both the trade and financial transactions increased from the mid-1990s to the mid-2000s. It is clear that the shrinkage or reversal of the trade and financial transactions from advanced economies have a significant impact on the rest of the world.

\section{GDP Growth Changes and Pre-Crisis Macroeconomic Factors}

In this section, we review the real GDP growth changes during the two crises and seven macroeconomic indicators of the pre-crisis periods for the 18 Asian economies. In calculating these indicators, the average values for three years prior to the two crises, the mid-1990s and mid- 2000s, were used (Note 5). By comparing the data of the two pre-crisis periods, we can determine whether the Asian economies became more robust or more vulnerable to external shocks. Seven macroeconomic indicators are selected based on literature review in section 2 and on the model developed in section 3. We arrange the indicators of each factor in several ways. First, we use the ratio of the each factor to the domestic output "GDP" to compare economies of different sizes on equal conditions. Second, to compare economies of different inflation rates on equal conditions, we consider GDP deflators as inflation rates where necessary, specifically when a factor is not handled as a ratio to GDP. Tables 2, 3 and 4 show the data and the mean values for the 18 economies, where paired data in both periods are available. The values in the line "t-test" are the $t$-values on the hypothesis that the sample means for paired data are equal (Note 6). The names of the economies in bold type in the tables are the ones that were heavily damaged and had a decline in real GDP growth of more than five percent during the Asian financial crisis.

\subsection{GDP Growth Changes}

First we review the most important phenomena during the financial crisis which is the dramatically decreased GDP growth, indicating turmoil in real economies and a severe decrease in production, leading to an increase in unemployment rates. GDP growth change (real) in the first column of Table 2 show that GDP growth decreased in almost all the economies in Asia during the two crises. To compare the data of the economies with different inflation rates on an equal basis, the values are adjusted by GDP deflators. It is notable that in the economies which were heavily damaged during the Asian financial crisis, such as Indonesia and Thailand, the GDP growth decreased much less during the crisis in 2008 than the crisis in 1998. On the contrary, in some economies such as Cambodia and Mongolia, it decreased much more during the crisis in 2008.

\subsection{Indicators of Pre-Crisis Macroeconomic Factors}

The seven macroeconomic indicators of the pre-crisis periods and the data are as follows.

\subsubsection{Foreign Debts and Risk Indicators}

For the factor of "foreign debt denominated in dollars: $D$ ", we use "total external debt by private creditors per GDP" (Note 7) as stock data. This indicator "captures foreign currency exposure and balance sheet effects: the higher the total external debt, the larger the increase in the real value of debt from a depreciation, and the stronger the adverse effect on output", as mentioned by Blanchard et al. (2010). The reason for limiting external debt to private creditors is that the debts by official creditors are negotiable for rollover or postponement of interest payments, whereas it is a difficult and lengthy process to negotiate with many private creditors. As shown in the second column of Table 2, this indicator decreased in most economies in Asia from the mid-1990s to the mid-2000s. It decreased significantly in some of the economies that were heavily damaged during the Asian financial crisis, such as Thailand and Indonesia. The lessons from the Asian financial crisis seem to have been effectively applied in this area. Exceptionally, this indicator increased for the Philippines and Korea.

For the factor "risk indicator: $x$ ", we use two indicators. The first indicator is "external short-term debt by private creditors per total reserves minus gold". If the total reserve dries up, an economy cannot maintain prior exchange rates by intervention, and the possibility of currency depreciation increases. A high value for this indicator decreases investors' trust in the corresponding currency. As tabulated in the third column of Table 2, this indicator decreased dramatically from the mid-1990s to the mid-2000s in most of the Asian economies, and all of the values for the mid-2000s were below 50 percent. This was one of the typical improvements resulting from the lessons of the Asian financial crisis. These improvements seem to have resulted from efforts to follow the advice of Alan Greenspan 
(1999). In line with a proposal by Pablo Guidotti, the Deputy Finance Minister of Argentina, Greenspan recommended that "countries should manage their external assets and liabilities in such a way that they are always able to live without new foreign borrowing for up to one year".

Another risk indicator is "current accounts per GDP", which has been suggested by many previous studies to be a statistically significant cause of financial crises as elaborated in section 2. A current account deficit means that imports are larger than exports, which sometimes suggests overheated domestic absorption. As suggested in formula (1), net capital inflow " $F$ " must be large enough to compensate the current account deficits, which increases additional external debts. As shown in the first column of Table 3, this indicator changed from deficits to surplus in two-thirds of the Asian economies from the mid-1990s to the mid-2000s. Those drastic changes occurred in the years after 1997 when Asian currencies depreciated considerably. Both exports and imports increased after 1997, but imports increased less than exports, so most of the Asian economies turned to their current account surplus. There were several exceptions staying in negative values such as Pakistan and Vietnam, however, these economies steadily improved their current account deficits.

\subsubsection{Capital Inflows and Money Supply}

For the factor of "net capital inflows: $F$ " we use "other investment liabilities (net) by bank and other sector per GDP" and "portfolio liabilities (net) per GDP". Net capital inflows are composed of net inflows of assets and liabilities, and the net inflows of liabilities are decomposed to net other investment liabilities, net portfolio investment liabilities, and net direct investment liabilities. We focus on net liabilities here because they most clearly indicate the change in capital inflows, and adding net assets might make the change in the capital inflows less distinct. We focus on net other investment liabilities and net portfolio investment liabilities among those components because net direct investment liabilities do not fluctuate significantly, even in the case of financial crises. These indictors show the degree of financial openness, mainly "other investment liabilities" to bank loans and trade credits and, similarly, "portfolio liabilities" to equity and debt securities markets. The continuing high values of these capital inflows increase outstanding foreign liabilities and lead to the vulnerability by financial contagion. The liabilities by official sectors are eliminated by the same reasons as the indicator of "total external debt by private creditors per GDP" noted above. In the second and third columns of Table 3, those two kinds of net capital inflows are listed. The average value of "other investment liabilities" did not change significantly between the mid-1990s and the mid-2000s, but the value of other investment liabilities decreased considerably in the heavily damaged economies during the Asian financial crisis, such as the Philippines, Malaysia and Thailand. The lessons from the Asian financial crisis seem to have been effectively applied in these economies. It is worth noting that the average value of "portfolio liabilities per GDP" increased from the mid-1990s to the mid-2000s for eight of eleven economies for which data are available in both periods. This finding reflects the expansion of international portfolio investments to the Asian economies. The increase in Taiwan and Malaysia are especially notable.

For the factor of "money supply: $M / P$ ", we use "growth of claims on the private sector per GDP". Usually, money supply " $M$ " is indicated by high-powered money plus quasi-money, " $M_{2}$ ". Quasi-money shares a large portion of the liabilities in depository corporations. Depository corporations determine the amount of credit to private sectors by multiplying their liabilities by the leveraged ratios according to their individual policies. The total amount of credit to the domestic private sector is indicated by the data "claims on private sectors". An overly high value for this indicator indicates a lending boom and a cause of non-performing loans, which leads to vulnerability in the financial sector to external shocks. As shown in the first column of Table 4, this indicator decreased from the mid-1990s to the mid-2000s. In many of economies that were heavily damaged, such as Thailand, Malaysia, the Philippines and Indonesia, the indicators in mid-2000s were at a low level, nearly below zero percent, indicating that the claims of the private sector grew at a level nearly equal to or less than the GDP growth. The facts suggest that the lessons of the Asian financial crisis were effectively applied in those economies. However, this indicator increased in a half of the economies, especially in such economies as Vietnam, Mongolia and Korea, who seem to have paid little attention to this indicator.

\subsubsection{An Indicator on Trade}

For the indicator "exports: EX", we use "exports per GDP". This indicator shows the degree of trade openness and the domestic economy's reliance on exports. This kind of trade expansion is welcome during ordinary periods; however, it may increase vulnerability to external shocks because of decreased outputs among trade partners. In the second column of Table 4 the values of this indicator are listed. For most of the Asian economies, the share of exports in the GDP expanded from the mid-1990s to the mid-2000s. There are two possible reasons for this expansion: the currency depreciation after 1997 and the shift in manufacturing industries from developed to developing economies in search of low costs. 


\section{Interlinked Phenomena during the Crisis}

As noted by Radelet and Sachs (2000) the Asian financial crisis involved several interlinked phenomena, such as the rapid reversal of private capital inflows into Asia, exchange rate depreciations, the sudden drop in bank lending and soaring domestic interest rates. In the following section, we compare the changes in seven indicators listed in section 3 between the mid-1990s and 1998 during the Asian financial crisis and the changes between the mid-2000s and 2009 during the global financial crisis. Tables 5, 6, and 7 show related indicators, mean values and the results of t-tests as noted in section 6 .

\subsection{Changes in Capital Inflows, Interest Rates Spreads and Money Supply}

Corresponding to the factor of "net capital inflows: $F$ " in the model, we analyze "change in other investment liabilities (net) by bank and other sector per GDP" and "change in portfolio liability (net) per GDP". The decrease in both net liabilities indicates a decline in capital inflows and forces the currency exchange rate to depreciate, resulting in various effects on domestic output. As shown in the first column of Table 5, the flow of "other investment liabilities" in Thailand, Indonesia, Korea, and the Philippines decreased more than eight percent during the Asian financial crisis, whereas the decreases in the same economies were less than three percent during the global financial crisis. The small outflows of "other investment liabilities" from Asian economies during the global financial crisis are surprising when compared to the change in other investment assets total of the five advanced economies which reversed sharply, from outflows in the mid-2000s to inflows in 2009, as in Table 1. It seems reasonable to think that the small outflows from Asian economies are attributed to the dramatically decreased risks indicated by "external short-term debt per total reserves" and "current accounts per GDP" in the mid-2000s, as shown in Table 2 and 3. Thus the small capital outflows in this area seem to be a result of the applied lessons from the Asian financial crisis.

In the second column of Table 5 the data show the changes in "portfolio liability" available. For this indicator, we compared the value for 2008, not 2009, to that for the mid-2000s (Note 8) because the portfolio investment assets in the five advanced economies promptly rebounded in 2009, as shown in Table 1 . The value decreased in half of the economies during the Asian financial crisis, whereas the value in all of the economies decreased during the global financial crisis in 2008. The average decrease was much larger during the global financial crisis than during the Asian financial crisis. This finding seems reasonable when we consider that the total portfolio investment assets of the five advanced economies reversed from outflows in the mid-2000s to inflows in 2008, whereas a slight increase, not a reversal, occurred from the mid-1990s to 1997 as in Table 1. The increased inflows of portfolio liabilities from mid-1990s to mid 2000s as in Table 3 seem also contributed to the larger decrease of portfolio liabilities during the global financial crisis.

For the factor of "interest rates spread between domestic lending rate and international lending rate: $r^{\wedge}-r^{*}$ ”, we use "change in the lending interest rates spread, between domestic and international lending interest rates". This spread affects the capital flow into and out of the Asian economies. We use 1-Year LIBOR on US dollars for the international lending interest rate, and calculate the changes in the spreads by the percentile change from the mid-1990s to 1998 and from the mid-2000s to 2009. We do not adjust the interest rates with inflation rates because it seems difficult for investors to estimate the inflation rates during the turmoil in financial crisis. The data are listed in the first column of Table 6. On average the spreads increased sharply during the global financial crisis, but it increased by relatively small percentages during the Asian financial crisis. The large increases in the spreads during the global financial crisis are mainly attributed to the drastic decline in international lending interest rates from the mid-2000s to 2009, as shown in Table 1. The increases in the spreads should have affected the capital flow out of Asian economies at a low level.

For the factor of "money supply denominated in national currency: $M / P$ ", we use "change in growth of claims on private sector per GDP" based on the indicator explained in section 6.2. In ordinary conditions during periods of output growth decline, governments try to increase credits (i.e. claims) on the private sector in the market through a money supply adjustment. An increase in the growth of claims on the private sector stimulates output growth. In the second column of Table 6, the data are listed. The average value changed from negative percentages during the Asian financial crisis to positive during the global financial crisis. In most economies, especially hard-hit economies during the Asian financial crisis such as Thailand and Malaysia, the indicator improved during the global financial crisis. The lessons learned seem to have been effectively applied in these economies. Exceptions to this finding are India, Korea, Mongolia, Pakistan and Sri Lanka, in which the growths show large negative values during the global financial crisis.

\subsection{Changes in Currency Exchange Rates and Real Foreign Debts}

Corresponding to the factor of "currency exchange rates: $e$ " in the model, we analyze the change in the nominal 
exchange rates, defined as US dollars per national currency (NC). As we can see from equation (2), the exchange rate does not affect GDP growth directly, but via two routes. The first is the balance sheet effect of the foreign debt over the exchange rate, " $D / e$ ". A depreciation of the currency increases the domestic value of the foreign debt and leads to the decline of output, GDP. The second route is the trade effect through the net export " $E X\left(e P^{*} / P, Y^{*}\right)$ $I M\left(e P^{*} / P, Y\right)$ ", in which a depreciation increases exports and decreases imports, boosting output if the Marshall-Lerner (ML) condition holds. The total effect depends on the relative strength of the two routes. In the first column of Table 7 the data are listed. Almost all economies experienced heavy currency depreciations during the Asian financial crisis, whereas most economies' depreciations during the global financial crisis were rather small, except Korea and Pakistan. One reason for the significant depreciations during the Asian financial crisis was that many Asian economies changed their exchange rate regimes to the more flexible ones to cover the shortage of reserves. On the other hand, they had enough reserves compared to the external short-term debt in mid-2000s as in Table 2. It seems reasonable to think that the small depreciation during the global financial crisis are attributed to the small capital outflows based on the dramatically decreased risks noted above in Asian economies. The applied lessons from the Asian financial crisis seem to lead to a good result during the global financial crisis.

Corresponding to the factor of "foreign debt denominated in domestic currency: D/e", we use "real change in external total debt by private creditors in national currency" calculated from the "total external debt (in US dollars) by private creditors per GDP", the "currency exchange rates: $e$ " and "GDP deflators". A large depreciation of a currency increases the real domestic value of the foreign debt and produces huge nonperforming loans. To compare the change during both crises on an equal basis, the indicators are calculated based on the value three periods before the crises. Thus, we align the values in 1994 and 2005 equal to 100 for the Asian financial crisis and the global financial crisis, respectively. We further adjust the value with GDP deflators to compare the economies with different inflation rates on an equal basis. In the second column of Table 7, the data are tabulated. The average value decreased, suggesting that the external debt burden did not increase during the global financial crisis as much as it did previously during the Asian financial crisis. Almost all economies showed less than a five percent increase in the global financial crisis in 2008, except Korea and India. These two exceptional economies increased the external total debt, and, in addition, Korea experienced a large depreciation of its currencies.

\subsection{Change in Trade}

Corresponding to the factor of "Exports: $E X$ ", we use "change in export growth per GDP"; the increase or decrease in export growth directly affects output growth. The reason we focus only on export growth and do not include imports is that the export growth most clearly indicates the change in the trade and, furthermore, imports are influenced by the domestic output " $Y$ ", and are not adequate to analyze as a factor of output " $Y$ ". As we can see in the third column of Table 7, export growth decreased in half of the Asian economies during the Asian financial crisis, whereas it increased in the other half of the economies. However, almost all economies experienced a decline in export growth during the global financial crisis, and the average value also drastically declined. It is reasonable to think that this significant decrease in export growth can be attributed to the sharp decline of imports of goods by advanced economies in 2009, as shown in Table 1.

\section{Conclusion}

A series of empirical analyses were conducted on the Asian financial crisis in 1997 and the global financial crisis in 2008 to determine whether the lessons from the Asian financial crisis have been effectively applied to the 18 Asian economies. This study showed that the application of these lessons differed according to macroeconomic factors. From the perspective of individual economies, many economies applied these lessons effectively, but some economies have paid little attention to them.

Concerning the pre-crisis status, the lessons learned from the Asian financial crisis seem to have been applied most effectively in two areas: the external short-term debts that came within half of the total foreign reserves, and the current accounts that changed from deficits to surplus (or decreased the deficits). Both of these areas improved in almost all economies. The levels of the total external debt by private creditors were lower during the mid-2000s in most of economies, specifically in the economies that were heavily damaged during the Asian financial crisis, such as Thailand and Indonesia. The lessons from the Asian financial crisis seem to have been applied effectively in those economies, while there were some exceptions such as the Philippines and Korea. The lesson that a lending boom, indicated by the high growth of claims on the private sector, should be avoided seems to have been applied effectively also in the economies that were heavily hit during the Asian financial crisis. However, some economies seem to have paid little attention to this lesson, such as Vietnam, Mongolia, and Korea. In addition to the lessons from the financial crisis, the portfolio capital inflows and exports increased in most economies, which might have increased vulnerabilities to external shocks. 
As a result of improvements in the macroeconomic pre-crisis status in Asian economies and the economic changes in the advanced economies during the crises, selected seven interlinked phenomena during crises show clear differences between the two crises. The differences in the mean values of the five indicators show the improvements that can theoretically mitigate external shocks. The reversal of capital inflow through external bank loans decreased, the currency depreciations were milder, and the credits to the private sector relaxed during the global financial crisis. In these changes, it seems that the lessons learned during the Asian financial crisis have been applied effectively. In addition, the interest rate spreads that affect capital inflow increased, and the balance sheet effects, which indicate the increase in the real external debt burden when converted to national currencies, decreased during the global financial crisis than during the Asian financial crisis. However, two indicators show an exacerbation of vulnerabilities to external shocks: a decline in portfolio investment inflows and a sharp decrease in export growth.

It is notable that the lessons learned were not applied consistently in all economies in Asia. The lessons during crises are not only for those who experienced disaster. Every economy is advised to apply the lessons learned by the other economies and to prepare for crises in the future.

\section{Acknowledgements}

I thank Professor Masaaki Komatsu, Professor Miki Ishida and Professor Masaru Ichihashi in Hiroshima University for invaluable advice and information.

\section{References}

Berkmen, P., Gelos, G., Rennhack, R., \& Walsh, J. P. (2009). The global financial crisis: Explaining cross-country differences in the output impact. IMF Working Paper, 09/280.

Blanchard, O. J., Faruqee, H., \& Das, M. (2010). The initial impact of the crisis on emerging market countries. Brookings papers on economic activity, 43, 263-323. http://dx.doi.org/10.1353/eca.2010.0005

Bussière, M., \& Mulder, C. (1999). External vulnerability in emerging market economies: How high liquidity can offset weak fundamentals and the effects of contagion. IMF Working Paper, 99/88.

Caramazza, F., Ricci, L., \& Salgado, R. (2000). Trade and financial contagion in currency crises. IMF Working Paper, 00/55.

Corsetti, G., Pesenti, P., \& Roubini, N. (2001). Fundamental determinants of the Asian crisis: The role of financial fragility and external imbalances. In T. Ito, \& A. O. Krueger (Eds.), Regional and Global Capital Flows: Macroeconomics Causes and Consequences: NBER-EASE 10, 11-46. Chicago: University of Chicago Press.

Forbes, K. J. (2002). Are trade linkages important determinants of country vulnerability to crises?. In S. Edwards and J. A. Frankel (Eds.), Preventing currency crises in emerging markets (pp. 77-130). Chicago: University of Chicago Press.

Glick, R., \& Rose, A. K. (1999). Contagion and trade: Why are currency crises regional?. Journal of International Money and Finance, 18 (4), 603-617. http://dx.doi.org/10.1016/S0261-5606(99)00023-6

Greenspan, A. (1999, April 29). Remarks by chairman Alan Greenspan; Currency reserves and debt. Before the World Bank Conference on Recent Trends in Reserves Management, Washington, D.C. [WWW page] URL http://www.federalreserve.gov/boarddocs/speeches/1999/19990429.htm.

Gregorio, J. D., \& Valdès, R. O. (2001). Crisis transmission: Evidence from the debt, tequila, and Asian flu crises. World Bank Economic Review, 15, 289-324. http://dx.doi.org/10.1093/wber/15.2.289

Lane, R. P., \& Milesi-Ferretti, G. M. (2010). The cross-country incidence of the global crisis. IMF Working Paper, $10 / 171$.

Llaudes, R., Salman, F., \& Chivakul, M. (2010). The impact of the great recession on emerging markets. IMF Working Paper, 10/237.

Radelet, S., Sachs, J. D., Cooper, R. N., \& Bosworth, B. P. (1998). The east Asian financial crisis: Diagnosis, remedies, prospects. Brookings papers on economic activity, 1998 (1), 1-90. http://dx.doi.org/10.2307/2534670

Radelet, S., \& Sachs, J. D. (2000). The onset of the east Asian financial crisis. In P. Krugman (Ed.), Currency crises (pp. 105-162). Chicago: University of Chicago Press.

\section{Notes}

Note 1. The 18 economies are Bangladesh, Brunei Darussalam, Cambodia, China P. R. Mainland, India, Indonesia, Korea, Lao P. D. R., Malaysia, Mongolia, Nepal, Pakistan, Papua New Guinea, the Philippines, Sri Lanka, Taiwan, Thailand, and Vietnam. 
Note 2. We do not normalize the domestic and foreign price level as Blanchard et al. did, because we wish to handle nominal data and real data distinctively.

Note 3. We handle " $\mathrm{r} \mathrm{r}_{-} \mathrm{r}$ ", " $\mathrm{x}$ " and " $(\Delta \mathrm{e} / \mathrm{e})_{\exp }$ " individually to capture the effects independently. We also retain the factor " $D / e$ " as an independent factor rather than decomposing it to the factors " $D$ " and " $e$ " because it plays an important role in the output growth change.

Note 4. Although some of the factors can be represented by the other factors, we list all the related factors to check the effect on the output " $Y$ " from many perspectives.

Note 5. For economies for which data for these three years are not fully available, data for one or two of these three years are used.

Note 6. Asterisks in the "t-test" show the rank of P-values, indicating the possibility that a mean value is larger (or smaller) than another mean value. $\left(* ; \mathrm{P}<0.10,{ }^{* *} ; \mathrm{P}<0.05,{ }^{* * *} ; \mathrm{P}<0.01\right)$

Note 7. The percentages of private creditors for the developing economies are estimated from World Bank data: \{"Private nonguaranteed (PNG), commercial banks and other creditors," + "public and publicly guaranteed (PPG), private creditors"\} divided by "external debt stocks, long-term". Because the data for Korea is not available, we assume it to be 100 percent in this paper.

Note 8. Similarly, we compared the value for 1997 , not 1998, to that for the mid-1990s, although no reversal occurred in 1997.

Table 1. Financial status and change; Five advanced economies

(United States, United Kingdom, Japan, Germany, France)

\begin{tabular}{|c|c|c|c|c|c|}
\hline Descriptor & (1994-96) av. & 1997 & 1998 & $\begin{array}{l}\text { 1997/(1994-96)av. } \\
-1\end{array}$ & $\begin{array}{l}\text { 1998/(1994-96)av. } \\
-1\end{array}$ \\
\hline GDP volume $\%$ change. Average of five economies. & 2.47 & & 1.98 & & $-19.8 \%$ \\
\hline 1-year US dep. London offer (LIBOR), \%. & 5.87 & & 5.53 & & $-5.8 \%$ \\
\hline $\begin{array}{l}\text { Other investment assets, total, } \\
\text { Bill. US dollars. }\end{array}$ & -299 & -870 & -119 & & $-60.2 \%$ \\
\hline $\begin{array}{l}\text { Portfolio investment assets, total, } \\
\text { Bill. US dollars. }\end{array}$ & -301 & -400 & -529 & $32.7 \%$ & $75.8 \%$ \\
\hline Descriptor & 1996 & 1997 & 1998 & & 1998/1996-1 \\
\hline $\begin{array}{l}\text { Goods imports: F.O.B., total, } \\
\text { Bill. US dollars. }\end{array}$ & -2120 & -2183 & -2219 & & $4.7 \%$ \\
\hline \multicolumn{6}{|l|}{ Global financial crisis } \\
\hline Descriptor & $(2005-07)$ av. & 2008 & 2009 & $\begin{array}{l}2008 /(2005-07) \text { av. } \\
-1\end{array}$ & $\begin{array}{l}2009 /(2005-07) \text { av. } \\
-1\end{array}$ \\
\hline GDP volume $\%$ change. Average of five economies. & 2.37 & & -4.22 & & $-277.8 \%$ \\
\hline 1-year US dep. London offer (LIBOR), \%. & 4.82 & & 1.57 & & $-67.4 \%$ \\
\hline $\begin{array}{l}\text { Other investment assets, total, } \\
\text { Bill. US dollars. }\end{array}$ & -2206 & 1196 & 1494 & & $-167.7 \%$ \\
\hline $\begin{array}{l}\text { Portfolio investment assets, total, } \\
\text { Bill. US dollars. }\end{array}$ & -1253 & 161 & -1011 & $-112.8 \%$ & $-19.3 \%$ \\
\hline Descriptor & 2007 & 2008 & 2009 & & 2009/2007-1 \\
\hline $\begin{array}{l}\text { Goods imports: F.O.B., total, } \\
\text { Bill. US dollars. }\end{array}$ & -4869 & -5422 & -4071 & & $-16.4 \%$ \\
\hline
\end{tabular}


Table 2.

\begin{tabular}{|c|c|c|c|c|c|c|c|}
\hline \multirow[t]{3}{*}{$\begin{array}{l}\text { Economy } \\
\text { name }\end{array}$} & \multicolumn{3}{|c|}{ GDP growth change (real) } & \multicolumn{2}{|l|}{$\begin{array}{l}\text { External } \\
\text { debt/GDP }\end{array}$} & \multicolumn{2}{|l|}{ Short-term debt/reserves } \\
\hline & 1998-(1994-96) & & 2009 - (2005-07) & $(1994-96)$ & $(2005-07)$ & (1994-96) & $(2005-07)$ \\
\hline & av. & & av. & av. & av. & av. & av. \\
\hline Bangladesh & & $0.7 \%$ & $-0.6 \%$ & $0.5 \%$ & $0.3 \%$ & $0.1 \%$ & $0.2 \%$ \\
\hline Brunei & & $-4.1 \%$ & $-3.4 \%$ & & & & \\
\hline Cambodia & & $-2.0 \%$ & $-13.3 \%$ & $0.2 \%$ & & $0.2 \%$ & \\
\hline China & & $-3.5 \%$ & $-3.5 \%$ & $10.1 \%$ & $7.1 \%$ & $17.8 \%$ & $9.6 \%$ \\
\hline India & & $-1.1 \%$ & $-0.4 \%$ & $9.0 \%$ & $8.4 \%$ & $9.2 \%$ & $6.2 \%$ \\
\hline Indonesia & & $-21.0 \%$ & $-1.3 \%$ & $26.1 \%$ & $16.8 \%$ & $76.7 \%$ & $11.9 \%$ \\
\hline Korea & & $-15.1 \%$ & $-4.4 \%$ & $18.2 \%$ & $28.7 \%$ & $153.9 \%$ & $46.7 \%$ \\
\hline Lao PDR & & $-3.4 \%$ & $-0.2 \%$ & & $35.1 \%$ & & \\
\hline Malaysia & & $-17.0 \%$ & $-7.6 \%$ & $29.4 \%$ & $23.5 \%$ & $23.8 \%$ & $12.5 \%$ \\
\hline Mongolia & & $-0.2 \%$ & $-10.0 \%$ & $6.1 \%$ & $1.1 \%$ & $0.9 \%$ & $0.2 \%$ \\
\hline Nepal & & $-2.7 \%$ & $1.0 \%$ & $1.4 \%$ & $0.1 \%$ & $0.1 \%$ & \\
\hline Pakistan & & $-2.0 \%$ & $-2.9 \%$ & $5.4 \%$ & $2.0 \%$ & $27.7 \%$ & $0.9 \%$ \\
\hline Papua N.G. & & $-7.2 \%$ & $1.0 \%$ & $22.2 \%$ & $7.8 \%$ & $20.1 \%$ & $4.1 \%$ \\
\hline Philippines & & $-5.5 \%$ & $-4.4 \%$ & $16.1 \%$ & $31.7 \%$ & $24.4 \%$ & $18.3 \%$ \\
\hline Sri Lanka & & $-0.3 \%$ & $-3.4 \%$ & $6.7 \%$ & $5.2 \%$ & $2.8 \%$ & $4.6 \%$ \\
\hline Taiwan & & $-3.0 \%$ & $-7.3 \%$ & & & & \\
\hline Thailand & & $-18.6 \%$ & $-7.2 \%$ & $35.3 \%$ & $14.1 \%$ & $73.7 \%$ & $17.5 \%$ \\
\hline Vietnam & & $-3.5 \%$ & $-3.1 \%$ & $7.4 \%$ & $3.8 \%$ & $13.4 \%$ & $2.5 \%$ \\
\hline Mean & & $-6.08 \%$ & $-3.93 \%$ & $13.85 \%$ & $10.75 \%$ & $34.18 \%$ & $10.40 \%$ \\
\hline Observations & & 18 & & 14 & & 13 & \\
\hline t-test & & -1.1975 & & 1.287 & & $2.6231 * *$ & \\
\hline
\end{tabular}

Table 3.

\begin{tabular}{|c|c|c|c|c|c|c|}
\hline \multirow[t]{2}{*}{ Economy name } & $\begin{array}{l}\text { Current } \\
\text { Accounts } \\
\text { /GDP }\end{array}$ & & $\begin{array}{l}\text { Other investment } \\
\text { liabilities/GDP }\end{array}$ & & $\begin{array}{l}\text { Portfolio } \\
\text { liabilities /GDP }\end{array}$ & \\
\hline & $\begin{array}{c}(1994-96) \\
\text { av. }\end{array}$ & $\begin{array}{c}(2005-07) \\
\text { av. }\end{array}$ & $\begin{array}{c}(1994-96) \\
\text { av. }\end{array}$ & $\begin{array}{c}(2005-07) \\
\text { av. }\end{array}$ & $\begin{array}{c}\text { (1994-96) } \\
\text { av. }\end{array}$ & $\begin{array}{c}(2005-07) \\
\text { av. }\end{array}$ \\
\hline Bangladesh & $-1.3 \%$ & $1.0 \%$ & $0.0 \%$ & $0.1 \%$ & $0.0 \%$ & $0.1 \%$ \\
\hline Brunei & & $29.3 \%$ & & $0.3 \%$ & & \\
\hline Cambodia & $-5.3 \%$ & $-4.7 \%$ & $-0.3 \%$ & $0.9 \%$ & & \\
\hline China & $0.8 \%$ & $9.0 \%$ & $-0.7 \%$ & $1.9 \%$ & $0.4 \%$ & $1.0 \%$ \\
\hline India & $-1.2 \%$ & $-1.0 \%$ & $1.0 \%$ & $2.3 \%$ & $1.1 \%$ & $1.7 \%$ \\
\hline Indonesia & $-2.7 \%$ & $1.8 \%$ & $0.2 \%$ & $0.2 \%$ & $2.1 \%$ & $1.9 \%$ \\
\hline Korea & $-2.3 \%$ & $1.0 \%$ & $3.8 \%$ & $3.6 \%$ & $2.9 \%$ & $1.8 \%$ \\
\hline Lao PDR & $-12.7 \%$ & $-0.3 \%$ & $0.0 \%$ & $0.5 \%$ & & \\
\hline Malaysia & $-6.7 \%$ & $15.7 \%$ & $2.5 \%$ & $-0.9 \%$ & $-1.0 \%$ & $2.1 \%$ \\
\hline Mongolia & $2.0 \%$ & $5.0 \%$ & $1.5 \%$ & $-1.3 \%$ & & \\
\hline Nepal & $-8.0 \%$ & $1.2 \%$ & $0.3 \%$ & $1.1 \%$ & & \\
\hline Pakistan & $-5.3 \%$ & $-4.8 \%$ & $1.5 \%$ & $0.5 \%$ & $1.1 \%$ & $1.3 \%$ \\
\hline Papua N.G. & $10.3 \%$ & $5.9 \%$ & $-9.3 \%$ & $0.4 \%$ & & \\
\hline Philippines & $-4.0 \%$ & $3.8 \%$ & $6.8 \%$ & $1.2 \%$ & $3.7 \%$ & $3.7 \%$ \\
\hline Sri Lanka & $-5.8 \%$ & $-4.1 \%$ & $2.6 \%$ & $0.5 \%$ & $-1.2 \%$ & $-1.0 \%$ \\
\hline Taiwan & $2.8 \%$ & $6.7 \%$ & $1.7 \%$ & $2.7 \%$ & $1.1 \%$ & $5.2 \%$ \\
\hline Thailand & $-7.2 \%$ & $1.0 \%$ & $8.4 \%$ & $1.9 \%$ & $2.1 \%$ & $2.6 \%$ \\
\hline Vietnam & $-8.2 \%$ & $-3.7 \%$ & $2.2 \%$ & $2.3 \%$ & & $4.2 \%$ \\
\hline Mean & $-3.23 \%$ & $1.98 \%$ & $1.31 \%$ & $1.05 \%$ & $1.12 \%$ & $1.86 \%$ \\
\hline Observations & 17 & & 17 & & 11 & \\
\hline t-test & $-3.5669 * * *$ & & 0.3052 & & $-1.6424 *$ & \\
\hline
\end{tabular}

1. The data of "Other Investment liabilities ((net) by bank and other sector)/GDP" for Cambodia and Lao PDR are bank sector only, and the data for Malaysia, Mongolia and Vietnam are other sector only, because of data availability. 
Table 4.

\begin{tabular}{|c|c|c|c|c|}
\hline \multirow{3}{*}{ Economy name } & \multirow{3}{*}{$\begin{array}{l}\text { Growth of claims } \\
\text { on priv. sector/GDP } \\
(1994-96) \mathrm{av} .\end{array}$} & \multicolumn{3}{|c|}{ Exports/GDP } \\
\hline & & & & \\
\hline & & (2005-07)av. & (1994-96)av. & (2005-07)av. \\
\hline Bangladesh & $2.1 \%$ & $1.8 \%$ & $10.3 \%$ & $18.4 \%$ \\
\hline Brunei & & $-3.1 \%$ & $56.9 \%$ & $69.9 \%$ \\
\hline Cambodia & $0.8 \%$ & $3.1 \%$ & $27.4 \%$ & $66.0 \%$ \\
\hline China & $-2.2 \%$ & $-4.2 \%$ & $20.5 \%$ & $38.2 \%$ \\
\hline India & $-0.1 \%$ & $3.1 \%$ & $10.5 \%$ & $20.3 \%$ \\
\hline Indonesia & $2.2 \%$ & $0.1 \%$ & $26.2 \%$ & $31.5 \%$ \\
\hline Korea & $1.3 \%$ & $4.8 \%$ & $27.8 \%$ & $40.3 \%$ \\
\hline Lao PDR & $0.5 \%$ & $0.2 \%$ & $23.6 \%$ & $35.8 \%$ \\
\hline Malaysia & $10.9 \%$ & $-2.2 \%$ & $91.6 \%$ & $114.7 \%$ \\
\hline Mongolia & $0.6 \%$ & $5.4 \%$ & $40.2 \%$ & $59.6 \%$ \\
\hline Nepal & $2.9 \%$ & $3.0 \%$ & $22.3 \%$ & $13.7 \%$ \\
\hline Pakistan & $0.0 \%$ & $0.3 \%$ & $16.6 \%$ & $15.0 \%$ \\
\hline Papua N.G. & $-1.2 \%$ & $2.5 \%$ & $58.0 \%$ & $78.9 \%$ \\
\hline Philippines & $7.5 \%$ & $-1.7 \%$ & $36.9 \%$ & $44.0 \%$ \\
\hline Sri Lanka & $-0.1 \%$ & $0.9 \%$ & $34.8 \%$ & $30.5 \%$ \\
\hline Taiwan & $2.1 \%$ & $1.9 \%$ & $45.6 \%$ & $67.5 \%$ \\
\hline Thailand & $11.9 \%$ & $-3.4 \%$ & $40.0 \%$ & $73.5 \%$ \\
\hline Vietnam & $0.2 \%$ & $11.5 \%$ & $35.9 \%$ & $73.3 \%$ \\
\hline Mean & $2.32 \%$ & $1.60 \%$ & $34.73 \%$ & $49.52 \%$ \\
\hline Observations & 17 & & 18 & \\
\hline t-test & 0.4515 & & $-4.7042 * * *$ & \\
\hline
\end{tabular}

1. The data of "Growth of claims on private sector/GDP" for Sri Lanka in 1995 is not used for the data discontinuity.

Table 5.

\begin{tabular}{|c|c|c|c|c|}
\hline \multirow[t]{3}{*}{ Economy name } & \multicolumn{2}{|l|}{$\begin{array}{l}\text { Change: (other inv. } \\
\text { liabilities /GDP) }\end{array}$} & \multicolumn{2}{|l|}{$\begin{array}{l}\text { Change: (portfolio } \\
\text { liability /GDP) }\end{array}$} \\
\hline & 1998 & 2009 & 1997 & 2008 \\
\hline & - (1994-96)av. & - $(2005-07) a v$. & - (1994-96)av. & - $(2005-07) a v$. \\
\hline Bangladesh & $0.1 \%$ & $-0.3 \%$ & $0.0 \%$ & $-0.1 \%$ \\
\hline Brunei & & $1.4 \%$ & & \\
\hline Cambodia & $0.3 \%$ & $-3.6 \%$ & & \\
\hline China & $0.4 \%$ & $-1.0 \%$ & $0.5 \%$ & $-0.8 \%$ \\
\hline India & $1.3 \%$ & $-2.0 \%$ & $-0.4 \%$ & $-2.9 \%$ \\
\hline Indonesia & $-12.5 \%$ & $0.2 \%$ & $-3.4 \%$ & $-1.3 \%$ \\
\hline Korea & $-9.7 \%$ & $-2.4 \%$ & $-0.3 \%$ & $-4.6 \%$ \\
\hline Lao PDR & $0.4 \%$ & $-0.9 \%$ & & \\
\hline Malaysia & $-2.3 \%$ & $0.8 \%$ & $0.7 \%$ & $-11.6 \%$ \\
\hline Mongolia & $2.6 \%$ & $1.9 \%$ & & \\
\hline Nepal & $-1.2 \%$ & $-0.7 \%$ & & \\
\hline Pakistan & $-4.1 \%$ & $-0.5 \%$ & $-0.6 \%$ & $-1.4 \%$ \\
\hline Papua N.G. & $2.0 \%$ & $1.7 \%$ & & \\
\hline Philippines & $-8.6 \%$ & $-2.9 \%$ & $-3.0 \%$ & $-6.2 \%$ \\
\hline Sri Lanka & $-3.4 \%$ & $-1.0 \%$ & $0.4 \%$ & $-0.2 \%$ \\
\hline Taiwan & $0.2 \%$ & $-2.6 \%$ & $-1.5 \%$ & $-9.1 \%$ \\
\hline Thailand & $-25.5 \%$ & $-2.7 \%$ & $0.9 \%$ & $-3.6 \%$ \\
\hline Vietnam & $-0.3 \%$ & $2.6 \%$ & & $-4.8 \%$ \\
\hline Mean & $-3.55 \%$ & $-0.78 \%$ & $-0.62 \%$ & $-3.81 \%$ \\
\hline Observations & 17 & & 11 & \\
\hline t-test & $-1.7115^{*}$ & & $2.6468 * *$ & \\
\hline
\end{tabular}


Table 6.

\begin{tabular}{|c|c|c|c|c|}
\hline \multirow[t]{2}{*}{$\begin{array}{l}\text { Economy } \\
\text { name }\end{array}$} & \multicolumn{2}{|l|}{$\begin{array}{l}\text { Change: lending } \\
\text { interest rate spread }\end{array}$} & \multicolumn{2}{|l|}{$\begin{array}{l}\text { Change: growth } \\
\text { (claims on priv. } \\
\text { sector/GDP) }\end{array}$} \\
\hline & $\begin{array}{l}1998 \\
/(1994-96) a v .-1 \\
\end{array}$ & $\begin{array}{l}2009 \\
/(2005-07) \text { av. }-1 \\
\end{array}$ & $\begin{array}{l}1998 \text { - } \\
(1994-96) \mathrm{av} .\end{array}$ & $\begin{array}{l}2009 \text { - } \\
(2005-07) a v .\end{array}$ \\
\hline Bangladesh & $2.1 \%$ & $26.6 \%$ & $-1.6 \%$ & $0.6 \%$ \\
\hline Brunei & & $479.6 \%$ & & $12.3 \%$ \\
\hline Cambodia & $0.5 \%$ & $20.5 \%$ & $-1.5 \%$ & $-2.1 \%$ \\
\hline China & $-83.4 \%$ & $138.4 \%$ & $10.8 \%$ & $27.7 \%$ \\
\hline India & $-15.8 \%$ & $55.4 \%$ & $0.3 \%$ & $-5.3 \%$ \\
\hline Indonesia & $109.0 \%$ & $31.8 \%$ & $-9.8 \%$ & $-1.5 \%$ \\
\hline Korea & $235.1 \%$ & $233.6 \%$ & $4.7 \%$ & $-6.0 \%$ \\
\hline Lao PDR & $20.6 \%$ & $-1.8 \%$ & $-0.9 \%$ & $6.8 \%$ \\
\hline Malaysia & $101.6 \%$ & $140.5 \%$ & $-12.9 \%$ & $18.7 \%$ \\
\hline Mongolia & $-73.6 \%$ & $-7.1 \%$ & $2.9 \%$ & $-5.4 \%$ \\
\hline Nepal & $19.3 \%$ & $99.6 \%$ & $2.0 \%$ & $14.6 \%$ \\
\hline Pakistan & $14.8 \%$ & $195.3 \%$ & $0.4 \%$ & $-6.5 \%$ \\
\hline Papua N.G. & $103.0 \%$ & $47.4 \%$ & $4.1 \%$ & $-1.1 \%$ \\
\hline Philippines & $25.1 \%$ & $47.9 \%$ & $-20.7 \%$ & $1.8 \%$ \\
\hline Sri Lanka & $-22.6 \%$ & $61.3 \%$ & $-0.6 \%$ & $-4.9 \%$ \\
\hline Taiwan & $25.8 \%$ & $-215.5 \%$ & $-1.1 \%$ & $-0.5 \%$ \\
\hline Thailand & $33.7 \%$ & $129.9 \%$ & $-21.8 \%$ & $6.1 \%$ \\
\hline Vietnam & $-38.1 \%$ & $34.8 \%$ & $0.1 \%$ & $11.0 \%$ \\
\hline Mean & $26.88 \%$ & $61.09 \%$ & $-2.68 \%$ & $3.17 \%$ \\
\hline Observations & 17 & & 17 & \\
\hline t-test & $-1.3676^{*}$ & & $-1.8573^{* *}$ & \\
\hline
\end{tabular}

1. The data of "Change in lending interest rate spread" for Pakistan are Money Market Rate.

2. "Change: growth of (claims on private sector/GDP)" for Sri Lanka in 1995 is not used for the data discontinuity.

Table 7.

\begin{tabular}{|c|c|c|c|c|c|c|}
\hline Economy name & $\begin{array}{l}\text { Change: exc. } \\
\text { rate } \\
1998 \\
/(1994-96) \\
\text { av.-1 }\end{array}$ & $\begin{array}{l}2009 \\
/(2005-07) \\
\text { av.-1 }\end{array}$ & $\begin{array}{l}\text { Change: real } \\
\text { external debt } \\
1998- \\
(1994-96) \text { av. } \\
(1994=100)\end{array}$ & $\begin{array}{l}2009- \\
(2005-07) a v . \\
(2005=100)\end{array}$ & $\begin{array}{l}\text { Change: exp. } \\
\text { growth/GDP } \\
\text { 1998- } \\
(1994-96) \\
\text { av. }\end{array}$ & $\begin{array}{l}2009- \\
(2005-07) \\
\text { av. }\end{array}$ \\
\hline Bangladesh & $-13.1 \%$ & $-2.5 \%$ & $0.0 \%$ & $0.0 \%$ & $0.8 \%$ & $-2.3 \%$ \\
\hline Brunei & $-13.3 \%$ & $9.0 \%$ & & & $-10.6 \%$ & \\
\hline Cambodia & $-32.1 \%$ & $-1.3 \%$ & $0.1 \%$ & & $-5.4 \%$ & $-14.4 \%$ \\
\hline China & $1.8 \%$ & $15.9 \%$ & $8.3 \%$ & $1.3 \%$ & $-2.0 \%$ & $-11.0 \%$ \\
\hline India & $-20.0 \%$ & $-10.1 \%$ & $0.8 \%$ & $21.8 \%$ & $0.1 \%$ & $-4.6 \%$ \\
\hline Indonesia & $-76.6 \%$ & $-9.7 \%$ & $48.6 \%$ & $-6.4 \%$ & $19.3 \%$ & $-5.2 \%$ \\
\hline Korea & $-43.0 \%$ & $-23.8 \%$ & $114.6 \%$ & $89.5 \%$ & $8.9 \%$ & $-5.2 \%$ \\
\hline Lao PDR & $-74.3 \%$ & $18.8 \%$ & & $4.9 \%$ & $11.5 \%$ & \\
\hline Malaysia & $-34.9 \%$ & $2.9 \%$ & $46.4 \%$ & $4.3 \%$ & $3.1 \%$ & $-13.4 \%$ \\
\hline Mongolia & $-45.1 \%$ & $-17.5 \%$ & $9.3 \%$ & $0.6 \%$ & $3.2 \%$ & $-7.3 \%$ \\
\hline Nepal & $-20.4 \%$ & $-9.6 \%$ & $0.4 \%$ & $0.0 \%$ & $-5.3 \%$ & $4.4 \%$ \\
\hline Pakistan & $-27.7 \%$ & $-26.3 \%$ & $1.0 \%$ & $2.4 \%$ & $-0.1 \%$ & $0.0 \%$ \\
\hline Papua N.G. & $-42.5 \%$ & $10.4 \%$ & $11.4 \%$ & $-5.2 \%$ & $-1.1 \%$ & $-19.1 \%$ \\
\hline Philippines & $-36.0 \%$ & $6.0 \%$ & $11.9 \%$ & $-8.2 \%$ & $-6.8 \%$ & $-4.7 \%$ \\
\hline Sri Lanka & $-19.8 \%$ & $-8.8 \%$ & $0.7 \%$ & $0.8 \%$ & $-0.7 \%$ & $-2.7 \%$ \\
\hline Taiwan & $-19.9 \%$ & $-1.8 \%$ & & & $-2.6 \%$ & $-18.3 \%$ \\
\hline Thailand & $-38.6 \%$ & $9.1 \%$ & $33.3 \%$ & $1.2 \%$ & $1.9 \%$ & $-14.1 \%$ \\
\hline Vietnam & $-17.0 \%$ & $-6.3 \%$ & $-0.8 \%$ & $1.6 \%$ & $-2.7 \%$ & $-14.8 \%$ \\
\hline Mean & $-31.81 \%$ & $-2.54 \%$ & $20.44 \%$ & $7.40 \%$ & $0.66 \%$ & $-8.30 \%$ \\
\hline Observations & 18 & & 14 & & 16 & \\
\hline t-test & $-5.2089 * * *$ & & $2.4072 * *$ & & $4.0626^{* * *}$ & \\
\hline
\end{tabular}

